\title{
EFFECT OF SOME ENVIRONMENTAL FRIENDLYTREATMENTS ON WHEATSPECIFIC AND TECHNOLOGICAL QUALITY
}

\author{
EL-Tellawy, F. M. ${ }^{(1)}$; Haggag, Wafaa, M. ${ }^{(2)}$ and Salama, M. A. \\ 1) Institute of Environmental Studies and Research, Ain Shams University \\ 2) Plant Pathology Department, National Research Center, Egypt.
}

\begin{abstract}
This work aimed to achieve effective use of some environmental friendly treatments of bio agents (Streptomyces lydicus -Trichodermaharziunum Trichodermaviride) on specific and technological quality of wheat. This study was carried out in the Abu Rawash province area, Giza Governorate during two successive seasons of 2014/2015 and 2015/2016.Two cultivars grain (Wheat Egypt 1, Wheat Egypt2) were used in this study. The maximum of 1000 grain fresh weight obtained in Streptomyces lydicus followed Trichodermaharziunum and Trichodermaviride in both seasons. While, the lowest value of 1000grain fresh weight were recorded in case of control application. Also, CV. Egypt 1 gave higher fresh weight/ 1000 grain weight, starch and wet- gluten high than CV. Egypt 2 in most cases in both seasons. Streptomyces lydicus treatment in wheat Egypt I recorded highest significant increased wet -gluten (33.33 and 33.60) followed by other treatments. While recorded treatment Streptomyces lydicus with Egypt 2 as compared with the control produced the lowest value with wheat Egypt 2 (27.36 and 27.13) in both seasons. Data showed that there is non-significant difference between Egypt 1 and Egypt 2 cultivars in water absorption in treatments Streptomyces lydicus, methyljasmonate and Trichodermaharziunum, while there is a significant increase in Egypt 2 compared with Egypt 1 cultivars in treatments with Trichodermaviride and control plants. Also, there is non-significant difference between Egypt 1 and Egypt 2 cultivars in arrival time and dough development time in treatments of Streptomyces lydicus, methyljasmonate, Trichodermaharziunum and control except treatment Trichodermaviride for rheological quality.
\end{abstract}


Keywords: Wheat, bio agent, gluten, water absorption.

\section{INTRODUCTION}

Egypt is the largest wheat importer worldwide (Gazette, 2013). Most of the domestic production of wheat goes into rural household consumption, where most farmers use the wheat to bake their own bread. According to the Food and Agriculture Organization of the United Nations (FAO) (2014), the area of cultivated wheat in Egypt is 1,336,234 hectares and the yield that comes out of it is 6.58 tons per hectare, resulting in a total wheat production of around 8,795,483 tons. Domestic wheat consumption in Egypt was $19,100,000$ tons, with constant population growth and decreasing arable land in Egypt, the risk to demand levels is ever increasing while, Egypt imported $10,593,506$ tons of wheat in addition to the consumption of the domestic production (Boutros, 2013).

Biological control involving microbial agents or biochemicals to control plant pathogens can be an eco-friendly and cost-effective component of an integrated disease management program (Mojibur et al, 2006). In wheat, grain treatment with several bacteria, including fluorescentpseudomonads, Pantoea sp., Bacillus cereus, and the fungus Trichodermaharzianum, has shown promise for control of Fusarium seedling blight caused by F. graminearum, F. culmorum, and Microdochiumnivale in glasshouse and field studies (Bello et al, 2002. Johansson et al, 2003). Many studies have shown that fluorescent pseudomonads, Pantoea sp., Bacillus spp., and T. harzianum are among the most effective microbes in controlling a range of soil borne diseases (Bello et al, 2002). 
This study aim to achieve effective use of some bio agent to increase the resistance of wheat against some diseases that afflict the ears of grain, Devise a safe and natural compounds to control some of the diseases of wheat and know the impact of both the user of agricultural products where biotechnology safe and natural compounds on both the quality and technological wheat.

\section{MATERIALS AND METHODS}

\section{Materials:}

1- Wheat Egypt grain (variety 1 and 2) were obtained from Agriculture Research Center. Giza, Egypt.

2- Bio agents(Streptomyces lydicus -Trichodermaharziunum Trichodermaviride and methyljasmonate) were obtained from National Research Centre. Giza, Egypt.

3- Chemical: All chemicals used in this study for analysis were of analytical grade.

This study was carried out in the Abu Rawash province area Giza Governorate during two successive seasons of 2014, 2015.Twocultivarsgrain were tested (Wheat Egypt 1, Wheat Egypt 2) and agriculture in the sandy soil nature of the ground in terms of the decline in the fertility rate, was carried out in accordance with the recommendations of the periodic bulletin of the Egyptian Ministry of Agriculture and were irrigated with closed basin surface system. Soil phsio- chemical characteristics determined according to the standard procedures outlined by Cottenie(1980) and presented in Table (1). 
J. Environ. Sci.

Institute of Environmental Studies and Research - Ain Shams University

Table (1): Soil physio-chemical characters.

\begin{tabular}{|c|c|}
\hline Physio-chemical characteristics & Results \\
\hline Sand \% & 88 \\
\hline Silt \% & 4 \\
\hline Clay \% & 7.2 \\
\hline Texture & Sandy \\
\hline $\mathrm{pH}(1: 2.5$ water $)$ & 0.83 \\
\hline $\mathrm{E} . \mathrm{C}(\mathrm{mmhos} / \mathrm{cm})(1: 2.5)$ & 4.8 \\
\hline $\mathrm{CaCO} \%$ & 0.24 \\
\hline $\mathrm{O} . \mathrm{M} \mathrm{\%}$ & 0.22 \\
\hline $\mathrm{P} \mathrm{ppm}$ & 10.18 \\
\hline $\mathrm{K} \mathrm{ppm}$ & 92.0 \\
\hline $\mathrm{Ca} \mathrm{ppm}$ & 18.4 \\
\hline $\mathrm{Mg} \mathrm{ppm}$ & 12.36 \\
\hline $\mathrm{Na} \mathrm{ppm}$ & 8.92 \\
\hline $\mathrm{Fe} \mathrm{ppm}$ & 8.34 \\
\hline $\mathrm{Mn} \mathrm{ppm}$ & 0.13 \\
\hline $\mathrm{Zn} \mathrm{ppm}$ & 0.10 \\
\hline $\mathrm{Cu} \mathrm{ppm}$ & \\
\hline & \\
\hline
\end{tabular}

Effect of some bio-safe compounds to increase the resistance of wheat against by some diseases that afflict the grain was studied. Four Environmental friendly treatments were used:( Streptomyces lydicus Trichodermaharziunum -Trichodermaviride and methyljasmonate) .The seeds were treated before planting and then sprayed the plants during different stages of growth follows as:

\section{Methods:}

1. Field experiments: The field was divided into five parts, with each part included in the treatment of (Streptomyces lydicus-

Trichodermaharziunum -Trichodermaviride-methyljasmonate and control 
). The treatments were carried out in the field by soaking the seeds (Wheat Egypt 1, Wheat Egypt 2 for 30 minutes in the biological solution, and the plants were sprayed on the plants at 45 days and 90 days.

\section{Analytical methods:}

\section{Physical properties:}

- Weight 1000 grain (g): Thousands grain weight are put seeds in counter mail seeds.

- Wet gluten: Wet gluten of wheat flour were determined using (Glutamic perten instruments, Hudding,Sweden) as described by perten (1990).

\section{Chemical analysis:}

- Determination of moisture:

- Grain moisture was determined using the non-destructive grain analyzer, Model Infratec TM 1241 Grain Analyzer, ISW 5.00 valid from S/N 12414500, 1002 5017/Rev.1, manufactured by Foss Analytical AB, Hoganas, Sweden.

- Determination of protein:

- The protein content was determined according to the method described in A.O.A.C. (1980).The protein content was calculated by multiplying total nitrogen percentage by 5.70 .

- Starch were determined according to the methods described by grain analyzer, Model Infratec TM 1241 Grain Analyzer, ISW 5.00 valid from S/N 12414500, 1002 5017/Rev.1, manufactured by Foss Analytical AB, Hoganas, Sweden. 


\section{Rheological properties:}

1. Farinograph test: Farinograph instrument (Barabender Duis Bur G made in West Germany) was used to determined the water absorption and mixing characteristics of dough prepared from the various treatments under investigation the following parameter were obtained from the Farinograms except the percentage of water absorption it was recorded directly from the farinograph instruments as described in the A.A.C.C(2000).The parameters obtained from the Farinograms follows as, arrival time (min),Dough development time (min),Stability time (min)and Degree of saftening (B.U.).

2. Statistical analysis: Treatments were replicated three times and statistical analysis using MSTAT package for analysis of variance (ANOVA) and means of treatments were compared using LSD at 0.05 according to (Snedecor and Cochran 1980).

Whereas, The Statistical analysis of farinograph was carried out using ANOVA with two factors under significance level of 0.05 for the whole results using SPSS (ver. 22). Data were treated as complete randomization design according to Steel et al. (1997). Multiple comparisons were carried out applying LSD.

\section{RESULTS AND DISCUSSION}

\section{Effect of different bio agents treatments on wheat grain quality:}

1. Fresh weight and Moisture: Table (2) showed that all treatment under study, significantly increase the 1000 grain of fresh weight as compared with the control in both seasons. While, Streptomyces lydicus recorded 
high significant 1000 grain of fresh weight (44.30 and 44.96) for season 1 and 2, respectively followed by Trichodermaviride and Trichodermaharziunum then my as compared with the control in a descending order. However, Table (2) show the effect of drenching and wheat grain treatments with different bio agent on fresh weight during two seasons, it's clear in table (2) that wheat Egypt I recorded high significant of 1000 grain fresh weight (40.72 and 40.84) than wheat Egypt 2 (39.46 and 39.63). Meanwhile, the effect of interaction between wheat cultivars and different bio agents Table (2) showed that Egypt I produced high significant 1000 grain of fresh weight (46.20 and 46.90) in both seasons followed by Streptomyces lydicus and Egypt 2 (42.40 and 43.03) as well as Trichodermaviride and Egypt 2 (42.70 and 42.80) as compared with the control produced lowest values with wheat Egypt I and Egypt 2 in both seasons.

Data show in Table (3) studied that no significantly different between all treatments when moisture was concerned in both seasons. On the other hand, no significantly describe different between both cultivars (Egypt I and Egypt 2) when moisture was concerned in both seasons. Also, the interaction between wheat cultivars and different bio agents failed to induce any statistical differences on moisture. 
J. Environ. Sci.

Institute of Environmental Studies and Research - Ain Shams University

Table (2): Effect of different bio agents on wheat fresh weight/1000 grain $(\mathrm{g})$ during two seasons.

\begin{tabular}{|c|c|c|c|c|c|c|}
\hline \multirow{2}{*}{ Bio agents } & \multicolumn{3}{|c|}{ Season1 } & \multicolumn{3}{c|}{ Season 2 } \\
\cline { 2 - 7 } & $\begin{array}{c}\text { Egypt } \\
\mathbf{1}\end{array}$ & $\begin{array}{c}\text { Egypt } \\
\mathbf{2}\end{array}$ & Mean & $\begin{array}{c}\text { Egypt } \\
\mathbf{1}\end{array}$ & $\begin{array}{c}\text { Egypt } \\
\mathbf{2}\end{array}$ & Mean \\
\hline Streptomyces lydicus & 46.2 & 42.4 & 44.3 & 46.9 & 43.03 & 44.96 \\
\hline Methyl jasmonate & 38.2 & 37.2 & 37.7 & 38.3 & 37.31 & 37.8 \\
\hline Trichoderma viride & 39.8 & 42.8 & 41.3 & 39.86 & 42.8 & 41.33 \\
\hline Trichoderma harziunum & 42.2 & 39.1 & 40.65 & 42.21 & 39.23 & 40.7 \\
\hline Control & 37.2 & 35.8 & 36.5 & 36.9 & 35.8 & 36.35 \\
\hline Mean & 40.72 & 39.46 & & 40.84 & 39.63 & \\
\hline Lsd treat & \multicolumn{3}{|c|}{1.4} & & \multicolumn{3}{c|}{0.71} \\
\hline Lsd variety & \multicolumn{3}{|c|}{2.63} & \multicolumn{3}{c|}{2.11} \\
\hline Lsd t*v & \multicolumn{3}{|c|}{ Ab } & & & \\
\hline According
\end{tabular}

According to, Moubarak and Abdel- Monaim (2011) showed that, in soil application method, the treatments of Trichoderma, Bacillus subtilis and Bacillus smegaterium had highest values for 1000 grain of fresh weight in the two seasons of wheat cultivars. Also, CV. Bain suif5 gave fresh and dry weights high then CV. Sakha93 in most cases.

Table (3): Effect of different bio agents on wheat moisture (\%) during two seasons.

\begin{tabular}{|c|c|c|c|c|c|c|}
\hline \multirow{2}{*}{ Bio agents } & \multicolumn{3}{|c|}{ Season1 } & \multicolumn{3}{c|}{ Season 2 } \\
\cline { 2 - 7 } & $\begin{array}{c}\text { Egypt } \\
\mathbf{1}\end{array}$ & $\begin{array}{c}\text { Egypt } \\
\mathbf{2}\end{array}$ & Mean & $\begin{array}{c}\text { Egypt } \\
\mathbf{1}\end{array}$ & $\begin{array}{c}\text { Egypt } \\
\mathbf{2}\end{array}$ & Mean \\
\hline Streptomyces lydicus & 10.7 & 10.6 & 10.65 & 10.7 & 10.6 & 10.65 \\
\hline Methyl jasmonate & 11.4 & 11.3 & 11.35 & 11.4 & 11.3 & 11.35 \\
\hline Trichodermaviride & 8 & 10.9 & 9.45 & 11.5 & 10.9 & 11.2 \\
\hline Trichodermaharziunum & 11.9 & 12 & 11.95 & 11.9 & 12 & 11.95 \\
\hline Control & 10.7 & 10.8 & 10.75 & 10.7 & 10.8 & 10.75 \\
\hline Mean & 10.54 & 11.12 & & 11.24 & 11.12 & Ns \\
\hline Lsd treat & \multicolumn{3}{|c|}{ Ns } & \multicolumn{3}{c|}{ Ns } \\
\hline Lsd variety & \multicolumn{3}{|c|}{ Ns } & \multicolumn{3}{c}{} \\
\hline Lsd t*v & \multicolumn{3}{|c|}{ Ns } & & & \multicolumn{3}{c|}{} \\
\hline
\end{tabular}


2. Wet gluten, protein and starch :Data in Table (4) obtained that the effect of wheat grain treatment with different bio agents on wet gluten under artificial infection during two seasons. It appears from Table (4) that values of wet gluten of wheat Egypt I was significantly higher than those of wheat Egypt 2 in both seasons. Meanwhile, the results presented in Table (4) reflects that increasing wet gluten levels induced positive effect on most studied bio agent treatment of both seasons. Whereas, Streptomyces lydicus recorded the highest significant wet-gluten than the control which produced lowest significant values is both seasons. Streptomyces lydicus treatment combined with wheat Egypt I recorded high significant wet gluten (33.33 and 33.60) followed by Trichoderma harziunum combined with wheat Egypt I as well as Streptomyces lydicus combined with wheat Egypt 2 as compared with the control produced the lowest value with wheat Egypt 2 (27.36 and 27.13) in both seasons. For study the effect of wheat grain treatment with different bio agents on protein under artificial infection during two seasons. The results in Table (5) showed that, Statistical differences were nil between all bio agents treatment when protein was concerned in the first season. Besides, Streptomyces lydicus treatment and control increased protein in the second season. However, there non-significant differences showed between wheat Egypt I and wheat Egypt 2 for protein in both seasons. Obtained in Table (6), wheat Egypt 2 cultivar statistically surpassed wheat Egypt1 in values of starch in both seasons. Meanwhile, reflects that increasing starch levels induced positive effect on most studied bio agent treatment of both 
seasons. Whereas, Streptomyces lydicus recorded the highest significant starch than the control which produced lowest significant values is both seasons. On the other hand, different combinations between (wheat Egypt I and Egypt 2) and different bio agents failed to induce significant differences as protein and starch parameters were concerned.

Table (4): Effect of bio agent treatments on wheat wet gluten during two seasons (\% on dry weight basis).

\begin{tabular}{|c|c|c|c|c|c|c|}
\hline \multirow{2}{*}{ Bio agent } & \multicolumn{3}{|c|}{ Season1 } & \multicolumn{3}{c|}{ Season 2 } \\
\cline { 2 - 7 } & $\begin{array}{c}\text { Egypt } \\
\mathbf{1}\end{array}$ & $\begin{array}{c}\text { Egypt } \\
\mathbf{2}\end{array}$ & Mean & $\begin{array}{c}\text { Egypt } \\
\mathbf{1}\end{array}$ & $\begin{array}{c}\text { Egypt } \\
\mathbf{2}\end{array}$ & Mean \\
\hline Streptomyces lydicus & 33.33 & 29.6 & 31.46 & 33.6 & 29.97 & 31.78 \\
\hline Methyl jasmonate & 26.76 & 27.56 & 27.16 & 26.97 & 27.7 & 27.33 \\
\hline Trichodermaviride & 27.16 & 28.23 & 27.7 & 27.23 & 27.95 & 27.59 \\
\hline Trichodermaharziunum & 29.73 & 28.36 & 29.05 & 29.93 & 28.23 & 29.08 \\
\hline Control & 27.6 & 27.36 & 27.48 & 28.07 & 27.13 & 27.60 \\
\hline Mean & 28.92 & 28.22 & & 29.16 & 28.19 & \\
\hline Lsd treat & \multicolumn{3}{|c|}{0.63} & \multicolumn{3}{c|}{0.66} \\
\hline Lsd variety & \multicolumn{3}{|c|}{1.89} & \multicolumn{3}{c|}{1.89} \\
\hline Lsd t*v & \multicolumn{3}{|c|}{} \\
\hline
\end{tabular}

Table (5): Effect of bio agent treatments on wheat protein\% during two seasons.

\begin{tabular}{|c|c|c|c|c|c|c|}
\hline \multirow{2}{*}{ Bio agent } & \multicolumn{3}{|c|}{ Season1 } & \multicolumn{3}{c|}{ Season 2 } \\
\cline { 2 - 7 } & $\begin{array}{c}\text { Egypt } \\
\mathbf{1}\end{array}$ & $\begin{array}{c}\text { Egypt } \\
\mathbf{2}\end{array}$ & Mean & $\begin{array}{c}\text { Egypt } \\
\mathbf{1}\end{array}$ & $\begin{array}{c}\text { Egypt } \\
\mathbf{2}\end{array}$ & Mean \\
\hline \hline Streptomyces lydicus & 13.4 & 12.5 & 12.95 & 13.5 & 12.8 & 13.16 \\
\hline Methyl jasmonate & 11.1 & 11.1 & 11.1 & 11.16 & 11.23 & 11.2 \\
\hline Trichodermaviride & 11.2 & 11.4 & 11.3 & 11.3 & 11.43 & 11.36 \\
\hline Trichodermaharziunum & 12.4 & 12.3 & 12.35 & 12.6 & 12.36 & 12.52 \\
\hline Control & 12.1 & 12 & 12.5 & 12.2 & 12 & 12.14 \\
\hline Mean & 12.04 & 11.86 & & 12.18 & 11.97 & \\
\hline Lsd treat & \multicolumn{3}{|c|}{ Ns } & \multicolumn{3}{c|}{1.30} \\
\hline Lsd variety & \multicolumn{3}{|c|}{ Ns } & \multicolumn{3}{c|}{ Ns } \\
\hline Lsd t*v & \multicolumn{3}{|c|}{ Ns } &
\end{tabular}


J. Environ. Sci.

Institute of Environmental Studies and Research - Ain Shams University

Table (6): Effect of bio agent treatments on wheat starch during two seasons.

\begin{tabular}{|c|c|c|c|c|c|c|}
\hline \multirow{2}{*}{ Bio agent } & \multicolumn{3}{|c|}{ Season1 } & \multicolumn{3}{c|}{ Season 2 } \\
\cline { 2 - 8 } & $\begin{array}{c}\text { Egypt } \\
\mathbf{1}\end{array}$ & $\begin{array}{c}\text { Egypt } \\
\mathbf{2}\end{array}$ & Mean & $\begin{array}{c}\text { Egypt } \\
\mathbf{1}\end{array}$ & $\begin{array}{c}\text { Egypt } \\
\mathbf{2}\end{array}$ & Mean \\
\hline \hline Streptomyces lydicus & 69.5 & 71.5 & 70.5 & 70 & 71.53 & 7.076 \\
\hline Methyl jasmonate & 67.9 & 69.7 & 68.8 & 68.1 & 69.5 & 68.8 \\
\hline Trichodermaviride & 69 & 69 & 69.01 & 69.4 & 69.1 & 69.27 \\
\hline Trichodermaharziunum & 67.2 & 68.3 & 67.7 & 67.33 & 68.37 & 67.85 \\
\hline Control & 64.5 & 67.3 & 65.9 & 65.1 & 67.57 & 66.08 \\
\hline Mean & 67.6 & 69.1 & & 67.99 & 69.12 & \\
\hline Lsd treat & \multicolumn{3}{|c|}{1.19} & \multicolumn{3}{c|}{0.95} \\
\hline Lsd variety & \multicolumn{3}{|c}{$\mathrm{ns}$} & \multicolumn{3}{c}{} \\
\hline Lsd t*v & \multicolumn{3}{|c|}{$\mathrm{ns}$} \\
\hline
\end{tabular}

3. Effect of bio agents on Farinograph parameters of wheat dough.: Data in Tables $(\vee)$ and (8) showed that there is were non-significant difference between Egypt 1 and Egypt 2 cultivars in water absorption for Streptomyces lydicus, methyljasmonate and Trichodermaharziunum treatments, while there is a significant increase in Egypt 2 compared with Egypt 1 cultivar in treatments Trichodermaviride and control. Also, there were non-significant difference between Egypt 1 and Egypt 2 cultivar in arrival time and dough development time in treatments Streptomyces lydicus, methyljasmonate, Trichodermaharziunum and control except treatment Trichodermaviride in both seasons.

On the other hand, data in the same Tables showed that there were nonsignificant difference between Egypt 1 and Egypt 2 cultivar in stability time in treatments of both seasons Streptomyces lydicus, methyljasmonate, Trichoderma viride and Trichoderma harziunum except treatment control. Further that there were non-significant difference between Egypt 1 and Egypt 130 
2 cultivar in degree of softening (weakening) in treatments Streptomyces lydicus, Trichodermaviride, Trichodermaharziunum and control except treatment methyljasmonate.

Table (7): Effect of bio agents on farinograph parameters of wheat dough first season.

\begin{tabular}{|c|c|c|c|c|c|c|c|c|c|c|}
\hline \multirow[t]{2}{*}{ Bio agent } & \multicolumn{2}{|c|}{$\begin{array}{c}\text { Water } \\
\text { absorptio } \\
\text { n }(\%)\end{array}$} & \multicolumn{2}{|c|}{$\begin{array}{c}\text { Arrival } \\
\text { time (min) }\end{array}$} & \multicolumn{2}{|c|}{$\begin{array}{c}\text { Dough } \\
\text { developmen } \\
\text { t time (min) }\end{array}$} & \multicolumn{2}{|c|}{$\begin{array}{c}\text { Stability } \\
\text { time (min) }\end{array}$} & \multicolumn{2}{|c|}{$\begin{array}{c}\text { Degree of } \\
\text { softening } \\
\text { (B.U) }\end{array}$} \\
\hline & $\begin{array}{c}\text { Egy } \\
.1\end{array}$ & $\begin{array}{l}\text { Egy } \\
.2\end{array}$ & $\begin{array}{c}\text { Egy } \\
.1\end{array}$ & $\begin{array}{l}\text { Egy } \\
.2\end{array}$ & $\begin{array}{c}\text { Egy } \\
.1\end{array}$ & $\underset{2}{\text { Egy. }}$ & $\begin{array}{c}\text { Egy } \\
.1\end{array}$ & $\begin{array}{l}\text { Egy } \\
.2\end{array}$ & $\begin{array}{l}\text { Egy } \\
.1\end{array}$ & $\begin{array}{l}\text { Egy } \\
.2\end{array}$ \\
\hline Streptomyces lydicus & 67.8 & 68.6 & 1.0 & 1.5 & 1.5 & 2.0 & 6.0 & 7.5 & 50 & 60 \\
\hline Methyl jasmonate & 65.7 & 66.4 & 1.5 & 2.0 & 1.5 & 2.0 & 7.5 & 7.0 & 100 & 30 \\
\hline Trichodermaviride & 58.8 & 64.0 & 2.5 & 1.0 & 3.0 & 2.0 & 7.5 & 8.0 & 90 & 60 \\
\hline $\begin{array}{c}\text { Trichodermaharziun } \\
\text { um }\end{array}$ & 66.1 & 69.3 & 1.5 & 1.5 & 1.5 & 1.5 & 6.5 & 6.0 & 90 & 50 \\
\hline Control & 62.9 & 73.1 & 2.0 & 1.0 & 2.0 & 1.5 & 10.5 & 7.0 & 70 & 90 \\
\hline L.S.D for treatment & \multicolumn{2}{|c|}{7.12} & \multicolumn{2}{|c|}{2.00} & \multicolumn{2}{|c|}{2.20} & \multicolumn{2}{|c|}{4.2} & \multicolumn{2}{|c|}{96.89} \\
\hline LSD for cultivars & \multicolumn{2}{|c|}{4.50} & \multicolumn{2}{|c|}{1.26} & \multicolumn{2}{|c|}{1.37} & \multicolumn{2}{|c|}{2.56} & \multicolumn{2}{|c|}{58.43} \\
\hline
\end{tabular}

Table (8): Effect of bio agents on farinograph parameters of wheat dough Second Season.

\begin{tabular}{|c|c|c|c|c|c|c|c|c|c|c|}
\hline \multirow[t]{2}{*}{ Bio agent } & \multicolumn{2}{|c|}{$\begin{array}{c}\text { Water } \\
\text { absorptio } \\
\text { n }(\%)\end{array}$} & \multicolumn{2}{|c|}{$\begin{array}{c}\text { Arrival } \\
\text { time (min) }\end{array}$} & \multicolumn{2}{|c|}{$\begin{array}{c}\text { Dough } \\
\text { developmen } \\
\text { t time (min) }\end{array}$} & \multicolumn{2}{|c|}{$\begin{array}{c}\text { Stability } \\
\text { time (min) }\end{array}$} & \multicolumn{2}{|c|}{$\begin{array}{c}\text { Degree of } \\
\text { softening } \\
\text { (B.U) }\end{array}$} \\
\hline & $\begin{array}{c}\text { Egy } \\
.1 \\
\end{array}$ & $\begin{array}{c}\text { Egy } \\
.2 \\
\end{array}$ & $\begin{array}{c}\text { Egy } \\
.1 \\
\end{array}$ & $\begin{array}{c}\text { Egy } \\
.2 \\
\end{array}$ & $\begin{array}{c}\text { Egy } \\
.1 \\
\end{array}$ & $\begin{array}{c}\text { Egy. } \\
2 \\
\end{array}$ & $\begin{array}{c}\text { Egy } \\
.1 \\
\end{array}$ & $\begin{array}{c}\text { Egy } \\
.2 \\
\end{array}$ & $\begin{array}{c}\text { Egy } \\
.1 \\
\end{array}$ & $\begin{array}{c}\text { Egy } \\
.2 \\
\end{array}$ \\
\hline Streptomyces lydicus & 68.0 & 69.1 & 1.0 & 1.5 & 2.0 & 2.0 & 6.0 & 8.0 & 50 & 60 \\
\hline Methyl jasmonate & 66.1 & 67.0 & 1.0 & 2.0 & 1.5 & 2.5 & 7.5 & 7.0 & 120 & 30 \\
\hline Trichodermaviride & 59.5 & 64.5 & 3.0 & 1.5 & 4.0 & 2.0 & 8.0 & 8.5 & 110 & 70 \\
\hline $\begin{array}{c}\text { Trichodermaharziun } \\
\text { um }\end{array}$ & 66.8 & 70.1 & 1.0 & 1.0 & 1.5 & 1.5 & 7.5 & 6.0 & 100 & 50 \\
\hline Control & 63.3 & 73.1 & 2.0 & 1.0 & 2.5 & 1.5 & 11.0 & 7.0 & 70 & 110 \\
\hline L.S.D for treatment & \multicolumn{2}{|c|}{7.16} & \multicolumn{2}{|c|}{2.04} & \multicolumn{2}{|c|}{2.24} & \multicolumn{2}{|c|}{4.42} & \multicolumn{2}{|c|}{100.67} \\
\hline LSD for cultivars & \multicolumn{2}{|c|}{4.53} & \multicolumn{2}{|c|}{1.29} & \multicolumn{2}{|c|}{1.42} & \multicolumn{2}{|c|}{2.80} & \multicolumn{2}{|c|}{61.67} \\
\hline
\end{tabular}


J. Environ. Sci.

Institute of Environmental Studies and Research - Ain Shams University

\section{CONCLUSION}

Streptomyces lydicus treatments it's surpassed in most of quality parameters compared with other treatments and control. while for rheological quality found that the best of treatments with Trichoderma viride and Nonsignificant difference between Egypt 1and Egypt 2 cultivars in water absorption and arrival time and dough development time with treatments Streptomyces lydicus, methyljasmonate,Trichoderma harziunum and control.

\section{REFERENCE}

A.A.C.C.(2000):.American Association of Ceereal Chemists. Aproved Methods of the A.A.C.C. Published by the American Asssociation of cereal Chemists,8th Ed.,St.Paul,M.N.USA.

A.O.A.C.(1980). Association of Official Analytical Chemists (1980): official and tentative methods of analysis. A.O.A.C., Washington, D.C.,U.S.A.

Bello, G. M. D.; Monaco, C. I., and Simon, M. R. (2002): Biological control of seedling blight of wheat caused by Fusariumgraminearum with beneficial rhizosphere microorganisms. World J. Microbiol. Biotechnol. 18:627-636.

Boutros, I. (2013): Reducing risks: Wheat supply in Egypt. Retrieved from http://www.dailynewsegypt.com/ reducing-risks-wheat-supply-inEgypt/ .

Cotteine, A. Soil Management for Conservation and Production. New York, 1980, pp. 245-250.

Fao,(2014): Http://www.egyptindependent.com/news/fao-wheat-productiondecline-2-2014.

Gazette, S. (2013, July 7). Egypt remains world's largest wheat importer. 
Johansson, P. M.; Johnsson, L., and Gerhardson, B. (2003): Suppres-sion of wheat-seedling diseases caused by Fusarium culmorum and Microdochiumnivale using bacterial seed treatment. Plant Pathol.52:219-227.

Mojibur R. Khan; Sven F.; Damian E.; and Fiona M. Doohan. (2006): Biological Control of Fusarium Seedling Blight Disease of Wheat and Barley. PHYTOPATHOLOGY. 96,. 4,: 387-394.

Moubarak. M.Y and M.F. Abdel- Monaim (2011): effect of bio-control agents on yield, yield components and root rot control in two wheat cultivars at new valley region 1 Egypt. Journal of cereals and oilseeds. Vol.2 (6): PP: 77-87.

Perten,H.(1990).Rapid measrement of wet gluten quality by the gluten index.Cereal Foods World,35(4):401-402.

Snedecor, W.B. and Cochran, G.W. 1980.Statistical Methods 6th Ed. Iowa State College. Press Amer Low, U.S.A.

Steel, R.; Torrie, J. and Dickey, D. (1997): Principles and procedures of Statistics: A Biometrical Approach, 3rd ed., McGraw-Hill, New York, NY.

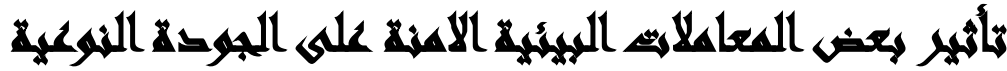

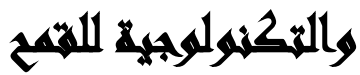

[V]

$$
\begin{aligned}
& \text { فاروق محمد التلاوي(') - وفاء محمد حجاج(؟) - محمد عبد الكريم سلامة } \\
& \text { ( ) معهد الدراسات والبحوث البيئية، جامعة عين شمس r ) الثُعبة الزراعيه والبيولوجيه المركز القومي } \\
& \text { لابحوث }
\end{aligned}
$$

\section{المستحلص}

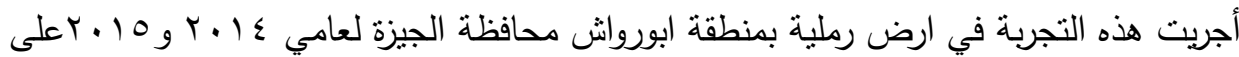

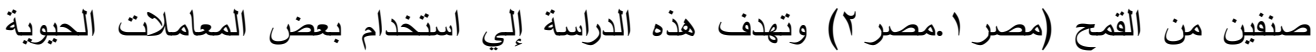

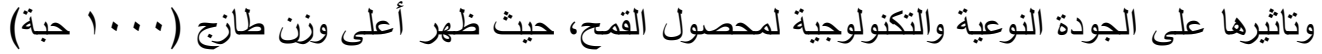

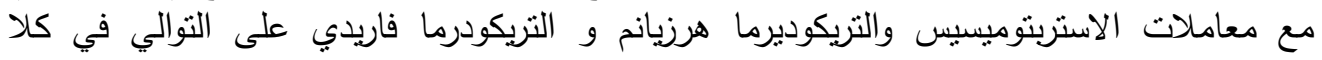


الموسمين في حين سجلت ادنى القيم في الوزن الطازج ( . . (1 حبة ) في حالة الكنترول، كذلك كان

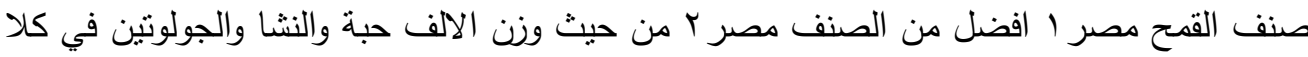

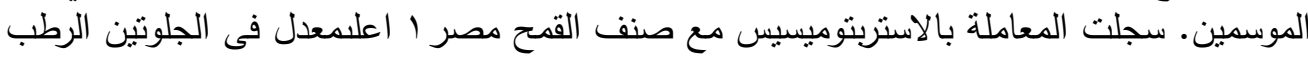

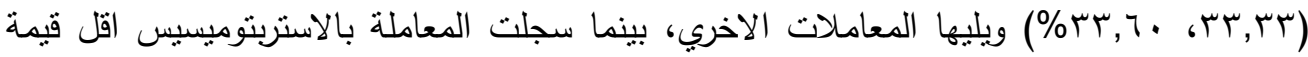

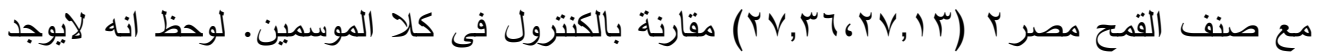

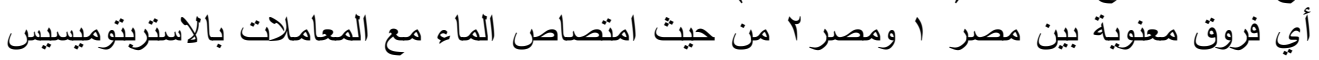

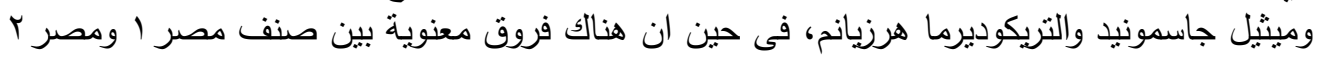

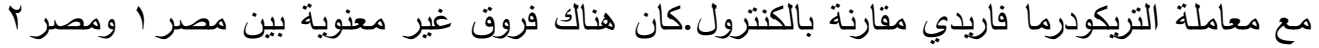

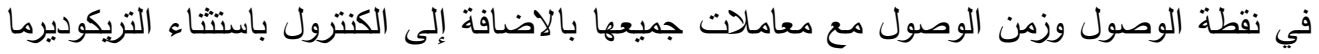
فاريدي بالنسبة للخواص الريولوجية. 